\title{
Synthesis of arachidonate cyclo-oxygenase products by rheumatoid and nonrheumatoid synovial lining in nonproliferative organ culture
}

\author{
J. A. SALMON ${ }^{1}$ G. A. HIGGS $,{ }^{1} \mathrm{~J} . \mathrm{R} \cdot \mathrm{VANE},{ }^{1} \mathrm{LUCILLE} \mathrm{BITENSKY,}{ }^{2}$ \\ J. CHAYEN ${ }^{2}$ B. HENDERSON ${ }^{2}$ AND B. CASHMAN ${ }^{3}$ \\ From the ${ }^{1}$ Department of Prostaglandin Research, Wellcome Research Laboratories, Langley Court, \\ Beckenham, Kent BR3 3BS; the ${ }^{2}$ Division of Cellular Biology, Kennedy Institute of Rheumatology, Bute \\ Gardens, London W6 7DW; and the ${ }^{3}$ Orthopaedics Department, Bedford General Hospital, Bedford
}

SUMMARY Specimens of human rheumatoid and nonrheumatoid synovial lining were maintained in nonproliferative organ culture for 20 hours. The culture fluids were then assayed for prostaglandin $\mathrm{E}_{2}\left(\mathrm{PGE}_{2}\right)$, thromboxane $\mathrm{B}_{2}\left(\mathrm{TXB}_{2}\right)$, and 6-keto-prostaglandin $\mathrm{F}_{1 \alpha}$ (6-keto-PGF $\left.\mathrm{F}_{1 \alpha}\right)$ by specific radioimmunoassay. The presence of each of these substances was confirmed by gas chromatography and mass spectrometry. Rheumatoid tissue produced significantly more of each cyclo-oxygenase product than nonrheumatoid tissue.

The initial step in the biosynthesis of prostaglandins from the unsaturated fatty acid precursor (for example, arachidonic acid) is the formation of unstable cyclic endoperoxides $\left(\mathrm{PGG}_{2}\right.$ and $\left.\mathrm{PGH}_{2}\right)$ by the enzyme fatty acid cyclo-oxygenase. The endoperoxides can be converted to thromboxane $A_{2}$ $\left(\mathrm{TXA}_{2}\right)$, prostacyclin $\left(\mathrm{PGI}_{2}\right)$, or the 'primary' prostaglandins $\left(\mathrm{PGE}_{2}, \mathrm{PGD}_{2}\right.$, and $\left.\mathrm{PGF}_{2 \alpha}\right)$ (review $\left.{ }^{1}\right)$.

It is now generally accepted that 'primary' prostaglandins, in particular $\mathrm{PGE}_{2}$, are important inflammatory mediators $\left(\right.$ review $\left.^{2}\right)$. These prostaglandins have been detected in human synovial fluids collected from inflamed joints, and concentrations are reduced after treatment with nonsteroid antiinflammatory drugs. ${ }^{34}$ Furthermore, tissue cultures of rheumatoid synovial lining produce prostaglandins. ${ }^{56}$ More recently thromboxane $B_{2}$ and 6-keto-PGF - $_{1 \alpha}$ (the stable hydrolysis products of thromboxane $A_{2}$ and prostacyclin respectively) have been detected in inflammatory exudates from experimental animals. ${ }^{7}$ Also, synovial effusions from rheumatoid joints have been found to contain thromboxane $\mathrm{B}_{2}$ and 6-keto-PGF $\mathrm{PG}_{1 \alpha}$ in addition to the 'primary' prostaglandins. ${ }^{89}$

In the present study we have investigated the capacity of human synovial lining tissue to generate cyclo-oxygenase products. Synovial explants have been maintained in nonproliferative organ culture, ${ }^{10}$

Accepted for publication 23 December 1981.

Correspondence to Dr J. A. Salmon. and tissue from rheumatoid and nonrheumatoid patients has been compared. Some of these resultso have been reported to the British Pharmacological? Society and to the Heberden Society. ${ }^{11}{ }^{12}$

\section{Materials and methods}

TISSUE CULTURE

Biopsy specimens of human synovial lining were taken either at arthrotomy for internal derangement or at synovectomy. The nonrheumatoid specimens were taken from the knee, either from quiescent joints or from otherwise normal joints after recent mechanical trauma. The rheumatoid specimens were taken mainly from the knee during synovectomy from patients who had 'definite' or 'classical' disease according to the diagnostic criteria of the American Rheumatism Association. ${ }^{13}$

All specimens were removed in a bloodless field within $10 \mathrm{~min}$ of the application of the tourniquet and were transferred to the laboratory in a sterile container on a gauze moistened with Trowell's T-8 culture medium (Gibco). The tissue was cut into segments, each of approximately $4 \times 4 \mathrm{~mm}$ planar surface and of the thickness of the membrane (not exceeding $4 \mathrm{~mm}$ ). These were maintained individually in Trowell's nonproliferative adult organ maintenance culture at the relevant $\mathrm{pH}$ for the tissue. ${ }^{14}$ For some segments the culture medium contained indomethacin (Wellcome) at $10^{-4} \mathrm{M}$. Explants were maintained under an atmosphere of $95 \%$ oxygen and $5 \%$ carbon dioxide at $37^{\circ} \mathrm{C}$ for 20 hours. 


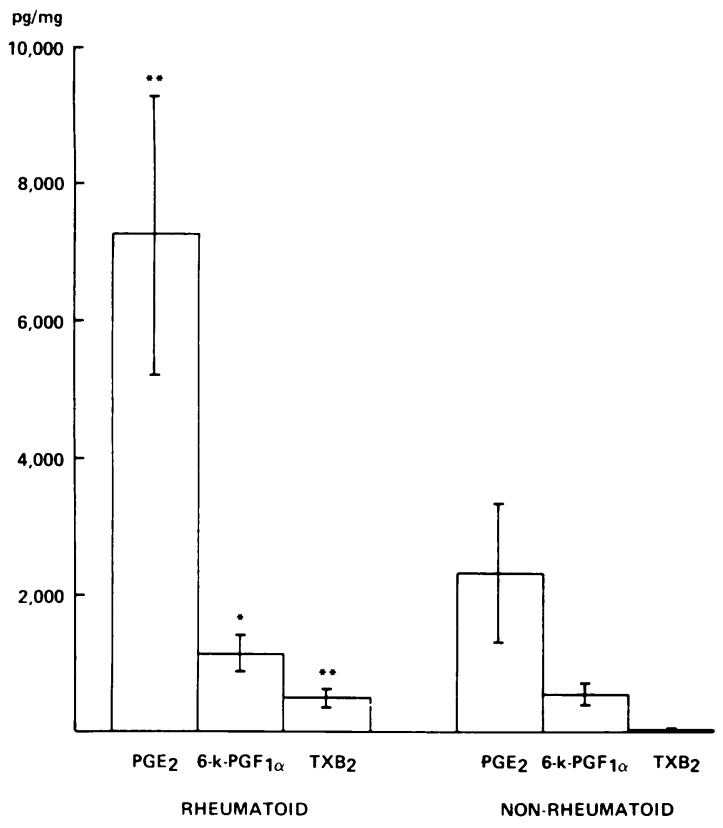

Fig. 1 Mean concentrations of prostaglandin $E_{2}\left(P G E_{2}\right)$ 6-keto-prostaglandin $F_{1 \alpha}\left(6-k-P G F_{1 \alpha}\right)$ and thromboxane $B_{2}\left(T X B_{2}\right)$ in culture media from rheumatoid $(n=9)$ and nonrheumatoid $(n=6)$ synovial explants. The bars represent $\pm S E$ mean.

${ }^{*} p<0 \cdot 1,{ }^{* *} p<0 \cdot 05$, compared with the nonrheumatoid group.

The medium was then withdrawn, snap-frozen to $-70^{\circ} \mathrm{C}$ and stored at $-20^{\circ} \mathrm{C}$. After removal of excess water each specimen was weighed, then chilled by precipitate immersion in n-hexane (BDH 'low in aromatic hydrocarbons' grade, boiling range $67-70^{\circ} \mathrm{C}$ ) at $-70^{\circ} \mathrm{C}$, and stored at $-70^{\circ} \mathrm{C}$ in a corked dry glass tube. Histological confirmation of the pathology was obtained from suitably stained cryostat sections of the explants, prepared as described by Chayen et al. ${ }^{15}$

\section{RADIOIMMUNOASSAY}

$\mathrm{PGE}_{2}, 6$-keto- $\mathrm{PGF}_{1 \alpha}$, and $\mathrm{TXB}_{2}$ in diluted culture media were assayed directly by radioimmunoassays. These assays are relatively specific, ${ }^{16}$ though $\mathrm{PGE}_{2}$ does cross-react significantly (approximately $5 \%$ ) in the assay for 6-keto- PGF ${ }_{1 \alpha}$. Therefore the cyclooxygenase products in several samples were extracted and separated by thin-layer chromatography prior to radioimmunoassay ${ }^{7}$ to confirm data obtained by direct assay. The amount of each cyclooxygenase product generated in the culture period was expressed as $\mathrm{pg} / \mathrm{mg}$ wet weight of tissue.
GAS-LIQUID CHROMATOGRAPHY AND MASS SPECTROMETRY

Cyclo-oxygenase products from 3 culture fluids were determined by gas liquid chromatography-mass spectrometry. Approximately $500 \mathrm{ng}$ of each of the following internal standards were added to each fluid; 3,3,4,4-D $\mathrm{D}_{4}$-6-keto- $\mathrm{PGF}_{1 \alpha}, \quad 5,6,8,11,12,14$, $15-\mathrm{D}_{7}-\mathrm{PGE}_{2}$, and $5,6,8,9,11,12,14,15-\mathrm{D}_{8}-\mathrm{TXB}_{2}$. The fluids were mixed with 2 volumes of ice-cold acetone to precipitate protein, and then the supernatant was washed with 2 volumes of $n$-hexane to remove neutral lipids. The remaining aqueousacetone phase was acidified to $\mathrm{pH} 4$ with citric acid and extracted twice with 2 volumes of chloroform. The combined extracts were evaporated to dryness and the residues were subjected to silicic acid column chromatography with mixtures of chloroform and methanol to elute the cyclo-oxygenase products. ${ }^{17}$ Fraction II, which contains $\mathrm{PGE}_{2}, \mathrm{TXB}_{2}$, and 6-keto-PGF ${ }_{1 \alpha}$, was concentrated to dryness and then reacted successively with methoxamine hydrochloride (Pierce Chemical Co.) diazomethane and N,O-bis-(trimethylsilyl)-trifluoroacetamide (BSTFA) containing $1 \%$ trimethylchlorosilane (TMCS; Pierce Chemical Co.) as previously described. ${ }^{7}$ Aliquots of the derivatised samples and standards were injected into a Hewlett-Packard Model 5730 A GLC combined with a VG Micromass $16 \mathrm{~F}$ mass spectrometer; a $1 \%$ OV 1 column was employed at $230^{\circ} \mathrm{C}$. The following ions were monitored: $\mathrm{m} / \mathrm{z} 301.20\left(\mathrm{TXB}_{2}\right), 305.23\left(\mathrm{D}_{8}-\mathrm{TXB}_{2}\right), 508.33$ $\left(\mathrm{PGE}_{2}\right.$ and 6-keto-PGF $\left.{ }_{1 \alpha}\right), \quad 512 \cdot 35 \quad\left(\mathrm{D}_{4}-6\right.$-keto$\left.\mathrm{PGF}_{1 \alpha}\right)$, and $515 \cdot 37\left(\mathrm{D}_{7}-\mathrm{PGE}_{2}\right)$. Under the chromatography conditions employed the retention times of the derivatives of $\mathrm{PGE}_{2}, \mathrm{TXB}_{2}$, and 6keto-PGF $\mathrm{PG}_{1 \alpha}$ were $5 \mathrm{~m} 58 \mathrm{~s}, 6 \mathrm{~m} 53 \mathrm{~s}$, and $7 \mathrm{~m} 32 \mathrm{~s}$ respectively.

\section{Results}

The results presented in Tables 1 and 2 and Fig. 1 are derived from radioimmunoassay of culture media directly. Culture fluids from samples 2207, 2208 (Table 1), and 2209 (Table 2) were extracted and purified before radioimmunoassay, and these experiments confirmed both the qualitative and quantitative results obtained by direct assay. The presence of $\mathrm{PGE}_{2}, 6$-keto- $\mathrm{PGF}_{1 \alpha}$, and $\mathrm{TXB}_{2}$ in extracts of culture fluids from sample 2342 (Table 2) was positively confirmed by gas-liquid chromatography and mass spectrometry.

All the culture fluids tested contained detectable concentrations of $\mathrm{PGE}_{2}$ and 6-keto-PGF ${ }_{1 \alpha}$, and in each case, with the exception of sample 2207 (Table 1), $\mathrm{PGE}_{2}$ was the predominant cyclo-oxygenase product. All the rheumatoid tissues produced significant amounts of $\mathrm{TXB}_{2}$, but in most cases it was the minor 
Table 1 Generation of cyclo-oxygenase products by nonrheumatoid synovial explants during 20 honproliferative culture

\begin{tabular}{|c|c|c|c|c|c|c|c|c|}
\hline \multirow[t]{2}{*}{ Patient } & \multirow[t]{2}{*}{ Sex } & \multirow[t]{2}{*}{ Age } & \multirow[t]{2}{*}{ Diagnosis } & \multirow[t]{2}{*}{ Joint } & \multirow[t]{2}{*}{ Treatment } & \multicolumn{3}{|c|}{ pg/mg wet wt. Synovial tissue } \\
\hline & & & & & & $P G E_{2}$ & $6-k-P G F_{1 \alpha}$ & $T X B_{2}$ \\
\hline 2207 & $\mathrm{~F}$ & 73 & Torn degenerated medial cartilage & Knee & None & 27 & 40 & 0 \\
\hline 2208 & $\mathrm{~F}$ & 13 & Chondromalacia & Knee & None & 2174 & 856 & 0 \\
\hline 2267 & $\mathbf{M}$ & 31 & Chondromalacia (diabetic) & Knee & Insulin & 7047 & 1017 & 105 \\
\hline 2270 & $\mathbf{M}$ & 43 & Torn meniscus & Knee & None & 936 & 690 & 17 \\
\hline 2316 & $\mathbf{M}$ & 19 & Torn meniscus & Knee & None & 2551 & 256 & 40 \\
\hline
\end{tabular}

Table 2 Generation of cyclo-oxygenase products by rheumatoid synovial explants during $20 \mathrm{~h}$ nonproliferative culture

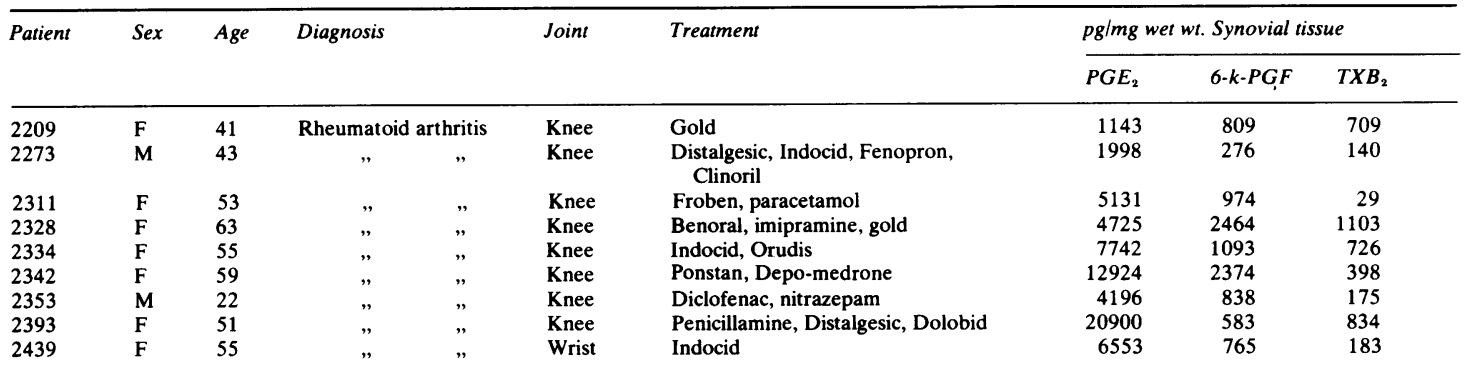

Proprietary names: Distalgesic (dextropropoxyphene), Indocid (indomethacin), Fenopron (fenoprofen), Clinoril (sulindac), Froben (flurbiprofen), Benoral (benorylate), Orudis (ketoprofen), Ponstan (mefenamic acid), Depo-medrone (methyl prednisolone), Dolobid (diflunisal).

product (Table 2). In 2 out of 6 cultures of nonrheumatoid tissues $\mathrm{TXB}_{2}$ was not detected (Table 1). The mean production of each cyclo-oxygenase product by rheumatoid tissue was significantly higher than mean values for the nonrheumatoid group (Fig. 1). Indomethacin $\left(10^{-5}\right.$ to $\left.10^{-3} \mathrm{M}\right)$ caused a dosedependent inhibition of the generation of each cyclo-oxygenase product and in tissues from 7 different patients $10^{-4} \mathrm{M}$ indomethacin suppressed cyclo-oxygenase activity by at least $85 \%$.

\section{Discussion}

The results presented in this paper confirm the observations that synovial lining explants produce $\mathrm{PGE}_{2}{ }^{56}$ and support the findings that rheumatoid synovium has a greater prostaglandin synthetase capacity than nonrheumatoid synovium. ${ }^{18} 19$ They also show that these tissues are capable of generating thromboxanes and prostacyclin, though $\mathrm{PGE}_{2}$ is the predominant product in both groups. It is possible therefore that the $\mathrm{TXB}_{2}$ and 6-keto-PGF ${ }_{1 \alpha}$ detected in synovial fluids ${ }^{8}{ }^{9}$ originate from synovial tissue.

Prostacyclin, like $\mathrm{PGE}_{2}$, is a potent vasodilator and hyperalgesic agent, ${ }^{2}$ and generation of prostacyclin as well as $\mathrm{PGE}_{2}$ by inflamed tissues could contribute to inflammatory symptoms such as erythema, oedema, and pain. The role of thromboxanes in inflammation is less clear. Thromboxane $A_{2}$ is a potent vaso- constrictor and aggregator of platelets, ${ }^{1}$ and thesec properties may reduce haemorrhage at an inflamed site. Also, thromboxane $\mathrm{B}_{2}$ has been reported to have chemotactic activity for leucocytes. ${ }^{20}$ There are, however, no reports as yet which indicate that thromboxanes are important inflammatory mediators. The increased cyclo-oxygenase activity in rheumatoid tissue may be fundamental to the rheumatoid process, or it may be a less specific consequence of the pathology of these joints.

Generation of cyclo-oxygenase products by synovial tissue in culture appears to be independent of prior drug treatment. Tissues from patients receiving nonsteroid anti-inflammatory drugs such as indomethacin, flurbiprofen, or diclofenac, which are known to inhibit prostaglandin synthesis, ${ }^{2}$ do not have significantly less cyclo-oxygenase activity than tissues from patients receiving other drugs (Table 2). These observations are in agreement with the findings that preparations of human synovial microsomes from patients receiving indomethacin, naproxen, or ibuprofen did not have decreased cyclo-oxygenase activity. ${ }^{21}$ These authors reported, however, that tissues from patients taking aspirin did not generate prostaglandins in vitro, and they attributed this to an irreversible effect of aspirin which was not shared by other nonsteroid anti-inflammatory drugs.

We thank Miss Lorna Tilling for excellent technical assistance. Some of us (L.B., J.C., and B.H.) gratefully acknowledge general support from the Arthritis and Rheumatism Council for Research. 


\section{References}

1 Moncada S, Vane J R. Pharmacology and endogenous roles of prostaglandin endoperoxides, thromboxane $\mathbf{A}_{2}$ and prostacyclin. Pharmacol Rev 1979; 30: 293-331.

2 Higgs G A, Moncada S, Vane J R. The mode of action of anti-inflammatory drugs which prevent the peroxidation of arachidonic acid. Clin Rheum Dis 1980; 61: 675-93.

3 Higgs G A, Vane J R, Hart F D, Wojtulewski J A. Effects of anti-inflammatory drugs on prostaglandins in rheumatoid arthritis. In: Robinson H J, Vane J R, eds. Prostaglandin Synthetase Inhibitors. New York: Raven Press, 1974: 165-73.

4 Robinson D R, Levine L. Prostaglandin concentrations in synovial fluid in rheumatic diseases: action of indomethacin and aspirin. In: Robinson H J, Vane J R, eds. Prostaglandin Synthetase Inhibitors. New York: Raven Press, 1974: 223-8.

5 Robinson D R, Smith H, McGuire M B, Levine L. Prostaglandin synthesis by rheumatoid synovium and its stimulation by colchicine. Prostaglandins 1975; 10: 67-85.

6 Sturge R A, Yates D B, Gordon D, Franco M, Paul W, Bray M, Morley J. Prostaglandin production in arthritis. Ann Rheum Dis 1978; 37: 315-20.

7 Higgs G A, Salmon J A. Cyclo-oxygenase products in carrageenin-induced inflammation. Prostaglandins 1979; 17: 737-46.

8 Trang L E, Granstrom E, Lovgren O. Levels of prostaglandins $F_{2 \alpha}$ and $E_{2}$ and thromboxane $B_{2}$ in joint fluid in rheumatoid arthritis. Scand J Rheumatol 1977; 6: 151-4.

9 Brodie M J, Hensby C N, Parke A, Gordon D. Is prostacyclin the major pro-inflammatory prostanoid in joint fluid? Life Sci 1980; 27: 603-8.

10 Trowell $\mathrm{O} A$. The culture of mature organs in synthetic medium. Exp Cell Res 1959; 16: 118-47.

11 Bitensky L, Cashman B, Chayen J, Henderson B, Higgs G A, Salmon J A, Vane J R. Synthesis of arachidonate cyclo-oxygenase products by rheumatoid and non-rheumatoid synovial tissue. Br J Pharmacol 1981; 72: 522P-523P.

12 Higgs G A, Salmon J A, Cashman B, Henderson B, Bitensky L, Chayen J, Vane J R. Products of cyclo-oxygenase activity from human synovium. Ann Rheum Dis 1981; 40: 190.

13 Ropes M W, Bennet G A, Cobb S, Jessar R A. Diagnostic criteria for rheumatoid arthritis. Ann Rheum Dis 1951; 18: 49.

14 Poulter L W, Bitensky L, Cashman B, Chayen J. The maintenance of human synovial tissue in vitro. Virchows Arch (Cell Pathol) 1970; 4: 303-9.

15 Chayen J, Bitensky L, Butcher R G. Practical Histochemistry. New York, London: Wiley, 1973.

16 Salmon J A. A radioimmunoassay for 6-keto-prostaglandin Fia. Prostaglandins 1978; 15: 383-97.

17 Salmon J A, Karim S M M. Methods for analysis of prostaglandins. In: Karim S $\mathbf{M}$ M, ed. Prostaglandins: Chemical and Biochemical Aspects. Lancaster: MTP. 1976: 25-85.

18 Chaintreuil J, Blotman F, Flandre O, Crastes de Paulet A, Simon L. Prostaglandin biosynthesis by normal and rheumatoid human synovial tissue: A comparative study on microsomes and whole homogenates. Eur J Rheumatol 1979; 2: 119-21.

19 Blotman F, Chaintreuil J, Poubelle P, Flandre O, Crastes de Paulet A, Simon L. $\mathrm{PGE}_{2}, \mathrm{PGF}_{2 \alpha}$ and $\mathrm{TXB}_{2}$ biosynthesis by human rheumatoid synovia. In: Samuelsson B, Ramwell P W, Paoletti R, eds. Advances in Prostaglandin and Thromboxane Research. New York: Raven Press, 1980: 8: 1705-8.

20 Kitchen E A, Boot J R, Dawson W. Chemotactic activity of thromboxane $B_{2}$, prostaglandins and their metabolites for polymorphonuclear leukocytes. Prostaglandins, 1978; 16: 239-44.

21 Crook D, Collins A J, Bacon P A, Chan R. Prostaglandin synthetase activity from human rheumatoid synovial microsomes. Effect of 'aspirin-like' drug therapy. Ann Rheum Dis 1976; 35: 327-32. 